Майденберг-Тодорова К. Естетична значимість композиторського задуму в алеаторно-сонористичній композиції Д. Курляндського «Бездротові технолоziï». Стаття присвячена вивченню проблемних текстових та інтерпретативних аспектів сучасної музичної творчості. На прикладі «Бездротових технологій» Д. Курляндського розкривається взаємодія специфічних композиторських засобів та авторської естетичної концепції в рамках сучасної алеаторно-сонористичної композиції.

Ключові слова: алеаторно-сонористнчна композиція, «периферійні звуки», артикуляційний тематизм.

Maidenberg-Todorova K. Aesthetic significance of composer intention into D. Kuorliandski's aleatoric-sonoristic composition «Wireless technologies». The article is dedicated to studying of problem textual and interpretative aspects of contemporary music art. The interaction of specific composers tools and aesthetic conception of author within contemporary alestoric-sonoristic composition reveals in the example of D. Kuorliandski’s «Wireless technologies».

Key words: aleatoric-sonoristic composition, «peripheral sounds», articulation thematism.

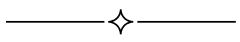

УДК $78.03+783.6$

\title{
T. Каплун
}

\section{ПРЕПОДОБНАЯ ЕВФРОСИНИЯ ПОЛОЦКАЯ В ДРЕВНЕРУССКОЙ ПЕВЧЕСКОЙ И ЖИТИЙНОЙ ТРАДИЦИИ}

В статье рассмотрены духовные и певческие аспекты воплощения образа святой Евфросинии Полоикой в древнерусской житийной и богослужебной традиции.

Ключевые слова: святость, житие святых, древнерусская певческая традиция, православное богослужение, Евфросиния Полоцкая, поэтика образа.

Евфросиния Полоцкая - один из самых светлых, тонких и чистых образцов древнерусской женственности, почитаемая святой преподобной как в православной, так и в греко-католической традиции. Святая дева, преподобная Евфросиния, основательница и первая игуменья полоцкого Спасо-Преображенского монастыря, инокиня и просветительница первой половины XII века, чья память приходится 
на 23 мая в православной традиции, 5 июня в греко-католической, а также на 3-ю Неделю по Пятидесятнице - в Соборе белорусских святых. На территории Беларуси Евфросиния Полоцкая, наряду с Кириллом Туровским, - одна из самых почитаемых святых. Ежегодно 5 июня в Полоцке традиционно широко празднуется День памяти преподобной [3].

Евфросиния представляет древний и славный род Рюриковичей - святая была правнучкой в пятом поколении равноапостольного князя Владимира Святославича, внучкой знаменитого полоцкого князя Всеслава Брячиславича и дочерью князя полоцкого Георгия (Святослава) Всеславича [3]. Исходя из изображений на кресте преп. Евфросинии, а также двух сохранившихся печатей, найденных в Новгороде и Кокнесе (Кукейнос, Латвия), исследователи предполагают, что мать ее звали Софией [8]. Род полоцких князей Всеславичей был могущественным и влиятельным: так, родная тетка преподобной Евфросинии была замужем за сыном греческого императора Алексея Комнина.

Жизненный путь святой был для эпохи средневековья достаточно длительным, охватывая более чем 70-летний период (родилась Предислава Святославична - будушая Евфросиния - в 1101 г., скончалась святая в 1173 г.). Жизнь преподобной не очень богата внешними событиями, но предельно насыщена интенсивной внутренней духовной жизнью.

Почитание ее во святых началось почти сразу после кончины в Иерусалиме, еще при жизни свт. Дионисия Полоцкого, по благословению которого, предположительно, была составлена служба и написано житие преподобной. Одновременно с созданием службы и жития была написана икона, до нас не дошедшая. Сохранилось лишь описание первого изображения Полоцкой игуменьи: «бледну лицем от пощения, ризы преподобнические, как у преподобномученицы Евдокеи» (цит. по: [15]).

В летописи имя полоцкой княжны Евфросинии не упоминается. Основные факты биографии и духовных исканий Евфросинии Полоцкой изложены в «Житии» святой, которое является одним из памятников раннего православия в Древней Руси и написано, согласно предположению А. И. Соболевского, Е. Е. Голубинского и архиепископа Филарета (Гумилевского), в домонгольский период. В основе агиографического памятника находится 3-частная структура, включающая риторическое вступление, повествование о жизненном пути святой 
и заключительную похвалу. В Житии отсутствует традиционный для данного жанра рассказ о посмертных чудесах [2, с. 147]. Но при этом важно учитывать, что произведение, созданное в конце XII в., дошло до нашего времени лишь в списках, не старше начала XVI в.

На сегодняшний день Житие известно более чем в 130 списках, представленных, согласно точке зрения современного исследователя А. А. Мельникова, шестью редакциями: это редакция Сборников, «Степенной книги царского родословия», Великих Миней-Четьих митрополита Макария, также две редакции Проложного Жития и «Книги житий святых» митрополита свт. Димитрия Ростовского (см.: [13, с. 128-129]).

В. О. Ключевский в книге «Древнерусские жития святых как исторический источник» пишет о близости состава и литературного характера жития полоцкой святой житиям XV-XVI вв., отмечая при этом, что «живость и обилие биографических черт вместе с остатками старинного языка заставляет предполагать у биографа какой-нибудь древний источник» [9, с. 262].

До первой половины XVI в. почитание прп. Евфросинии не выходило за пределы Великого княжества Литовского, и святая игумения не была известна в Московской Руси до тех пор, пока ее житие свт. Московский Макарий не включил в Великие Четьи-Минеи [15].

Опишем основные моменты «Жития Евфросинии Полоцкой» в контексте поставленной в нашей работе задачи - выявление круга духовных качеств святой (автор данной статьи в своем анализе житийного текста опирается на 1-й вариант редакции Жития [7], который, по мнению А. А. Мельникова, «наиболее близок гипотетическому архетипу произведения» $[10$, с. 28$]$, а также на текст «Степенной книги царского родословия» [20]).

Житие рисует характер святой девы рано сложившимся, с юных лет Предслава задумывается о тленности земной славы: «...что бо успеша прежде нас бывше роди наши? женишася, посягаша и княжиша, но не вечноваша; житие их мимо тече и слава их погибе яко прахъ и хуже паутины» [6, с. 3]. Также в Житии говорится о рано проявившихся способностях и особой любви к учению Предславы, которая много читала, хорошо знала Псалтирь и Свящ. Писание, так что отец дивился столь редкому для девочки свойству. Решение покинуть родительский дом и стать инокиней было самостоятельным. В этом поступке отражается родовой женский характер полоцких княгинь решительность и самостоятельность выбора. Возможно, тайный 
характер пострига был продиктован намерением отца выдать дочь замуж, чего она желала избежать. В Житии Предславы впервые семейная жизнь женщины характеризуется как пример тленных забот $[11$, с. 75-76]. Любовь к книжному учению сочеталась у нее с усердной молитвой, внешняя красота («бяше бо лепа лицем» [7]) - с целомудрием и глубокой сосредоточенностью («Вести же разшедшейся по всем градом о мудрости ея и о блазем учении ея» [7]).

В 12 лет она приняла монашеский постриг под именем Евфросиния в честь преподобной Евфросинии Александрийской, что отнюдь не случайность, поскольку Александрия - это и знаменитый оазис учености, прославленный библиотекой и Мусеем, родина великих богословов раннего христианства Климента и Оригена, родина святителей Александра Александрийского и Афанасия Великого. Иноческий сан святая приняла в полоцком женском монастыре, игуменьей которого была ее тетя - вдова князя Романа Всеславича («нъ духовным мечем отсекоша от себе плотскыя сласти, предавше телеса своя на пост и на бдение и коленное покланяние и на земли легание» [7]). Евфросиния много читала и с разрешения епископа Полоцкого Илии поселилась в келье («голубце каменне») при кафедральной полоцкой церкви Св. Софии, в которой находилась хорошая библиотека. Святая занималась переписыванием книг по заказам горожан, полученные деньги раздавала как милостыню («и ту вшедши... начатъ книги писати своима рукама, наемъ емлющи (т. е. получая плату), требующимъ (нуждающимся) даяше» [7]).

Не позднее 1128 г., в княжение дяди Евфросинии полоцкого князя Бориса Всеславича, епископ передал княжне-инокине «место» (храм) при церкви Св. Спаса на Сельце близ Полоцка, где возник девичий Спасо-Преображенский монастырь, игуменьей которого стала Евфросиния. На свои средства преподобная выстроила в монастыре и украсила церковной утварью и росписями церковь Св. Спаса. Здесь приняли иночество многие родственницы Евфросинии (младшая сестра Евдокия, двоюродная сестра Евпраксия, племянницы Агафья и Евфимия). Святая дева учила монахинь грамоте, переписыванию книг, пению, шитью и иным ремеслам, чтобы с юности они знали закон Божий и имели навык к трудолюбию [7]. А более всего - терпению и воздержанию, душевной чистоте и смирению. В Житии приведены два фрагмента поучений полоцкой игумении. Их основной темой является преображение внутреннего человека ради приближения к Богу: «Нивы ваша во едину меру стоят, не растуще, ни 
поступающе горе, а год приспевает во свершение... Потьщитеся, чада моя... сотворитеся пьшенице и смелетеси в жерновах смирением, и молитвами, и постом, да хлеб чист принесетеся на трапезу Христову» [20, c. 214].

Помимо девичьего монастыря преп. Евфросиния устроила поблизости и мужской монастырь с церковью во имя Пресв. Богородицы. Активная церковно-политическая деятельность игуменьи выходила далеко за пределы Полоцка, также из Жития преподобной известно о ее сотрудничестве с полоцким епископом Дионисием, преемником Ильи [7].

Незадолго до своей кончины, ок. 1172/73 г., полоцкая игуменья вместе со своей сестрой Евпраксией и братом Давыдом, совершила паломническую поездку в Святую Землю и по дороге, по свидетельству Жития, была в Константинополе принята «с великою честью» императором и патриархом. Добравшись до Иерусалима, преподобная остановилась в Русском монастыре Пресв. Богородицы. Евфросиния преставилась 23 (или 24) мая 1173 г. и была похоронена в палестинском монастыре преп. Феодосия Великого. В 1187 г. Иерусалим завоевал султан Саладин, который потребовал от христиан в пятидесятидневный срок покинуть город, предварительно выкупив свою жизнь. Монахи русского монастыря, возвращаясь на родину, взяли с собой святые мощи русской княжны, которые были перенесены ими в Киево-Печерскую лавру [1].

«Жизнь преподобной Евфросинии целиком включена в жизнь древнерусского общества. Она - просветительница: сама учила в созданной ею же школе, переписывала книги. Полоцкая игуменья миротворица... в силу своего авторитета и родственных связей умиротворяла соседей, предотвращая распри и ссоры. Она - храмостроительница, духовная попечительница» [11, с. 77-78].

В пояснениях к канону святой современный богослов Симеон писал: «Прп. Евфросиния представляет собою тип характера, который был ярко проявлен в Киевской Руси, но гораздо менее свойственен Руси Московской. Русских в IX-XII вв. роднило с другими северными народами - германцами, англосаксами, кельтами - принятое в обществе достаточно высокое представление об умственном и духовном потенциале женщины. В эпосе и в ранней истории этих народов женщина часто выступает в роли, которая ей мало свойственна по природе - как воительница-богатырша [...] В жизни прп. Евфросинии я вижу такие черты раннего русского христианства... 
как гармоничное и оптимистическое восприятие жизни и общества, склонность к освящению и преображению мира, а не к уходу из него. Высокое сознание ответственности женщины, не замыкающейся в тесном кругу домашних забот, а вносящей дух материнской молитвы, любви и заботы в разделенный враждой, корыстью и амбициями мир мужчин, - это кажется столь современным, столь нужным именно теперь, что образ прп. Евфросинии приобретает символический смысл» [19].

Духовный путь Евфросинии относится к типу преподобнического служения святых дев X-XIII вв., характерного для древнекиевского периода. При этом она представляет молитвенно-трудовую культурную тенденцию в женском монашестве Древней Руси в отличие от молитвенно-созерцательного типа иноческого пути другой преподобной девы этого периода - Евфросинии Суздальской [20].

Далее рассмотрим круг духовных качеств святой Евфросинии Полоцкой, представленный в древнерусском певческом материале. Сперва коснусь источниковедческого аспекта изучения указанного пласта. Автором статьи на сегодняшний день выявлены 10 певческих рукописей, содержащих песнопения службы памяти прп. Евфросинии Полоцкой 23 мая. Это кодексы ряда российских хранилищ (РНБ, БАН, РГБ и ГИМ), относящиеся к различным векам древнерусской традиции и содержащие различное количество песнопений святой: к числу наиболее древних относится рукописный источник конца XII в. (РНБ, Соф. собр. № 96) - Триодный Стихирарь писца Иоанна, созданный, по предположению А. Мельникова, в Свято-Преображенском или в Богородичном монастырях [12, с. 29] и включающий стихиру «Придете, любомоудьрии». Указанная стихира, в силу плохой сохранности листа рукописи с песнопением, была реконструирована медиевистом Н. Серегиной методом сопоставления крюковой строки с источниками XVI-XVII вв. (см.: [18, с. 129-130 и рис. 23-24; 17, с. 96]). В списках XVI-XVII вв. данная стихира с инципитом «Придите, любомудрьнии» замыкает цикл стихир «на хвалитех» 6-го гласа. Указанный текст распет развитым напевом с наличием фит на словах «молящи» и «Творцу», которые подчеркивают глубинный смысл стихиры, и представляет собой троегласник, т. е. распевалась тремя гласами попеременно соответственно частям текста [18, с. 131]. Считая вопрос о точности реконструкции певческой части стихиры требующим дополнительного рассмотрения, обратимся к источникам более позднего времени - конца XVI - первой половины XVII вв., где мы 
находим значительно расширенный состав певческой части службы святой, в ряде рукописей присутствуют полные певческие циклы (без канонов): мини-циклы стихир Вечерни («на Господи воззвах» 4-го гласа, «на хвалитех» 6-го гласа, «на стиховне» 2-го гласа, «на литии» 2-го гласа), славники 6-го гласа.

Почитание святой княжны долгое время носило местный характер, ограничиваясь Полоцкой епархией, а между XIII в. и 1514 г. почитание Ефросинии, возможно, установилось в Смоленске [5], что объясняет крайне небольшое количество сохранившихся источников древнейшего периода. Последующее расширение круга памятников во второй половине XVI века напрямую связано с канонизацией группы святых на церковных соборах 1547-1549 гг., а также с вхождением Жития святой в макариевские Четьи-Минеи.

Современная служба на преставление прп. Евфросинии была принята в общецерковное употребление в 1893 г. [15]. В начале XX в. расширяется количество песнопений святой, появляется Акафист и в 1910 г. создается новая служба на перенесение честных мощей преподобной из Киево-Печерской лавры, где хранились до этого времени мощи святой, в Полоцк, в основанный ею монастырь, где они покоятся в настоящее время (подробнее см.: [16 и 4, с. 89]).

Предметом нашего анализа являются древнерусские певческие источники конца XVI - первой половины XVII вв., зафиксированные знаменной беспометной (рукописи конца XVI в.) и пометной, призначной (середина XVII в.) формами нотации. Сопоставим определения духовных качеств, представленных в житийном тексте, а также в вербальной и в невменной строках певческих рукописей. Для большей наглядности сведем выявленные в указанных источниках сведения в следующую таблицу (см. на с. 272).

В таблице представлены фитные распевы и маркированные ими самые значимые слова богослужебного текста: «блаженная», «еси», «Богови», «радоуися», «моужески», «молящися», «Творцу», «непрестаи», «попрала еси», «мужество», «псаломенсы», «оудобрения». Указанный ряд составляет своего рода богослужебный метатекст, выделенный мелизматическими пространными мелодическими образованиями (см. на с. 273).

Отмечу также факт применения в службе группы четных гласов 2-й, 4-й и 6-й. Если принять во внимание духовно-символический смысл указанных гласов, то выявляется следующий круг богословских православных идей (трактовка дана по 3): 


\begin{tabular}{|c|c|c|c|}
\hline качество & житие & Текст песнопения & Ботослүжебный жанр \\
\hline \multirow[t]{3}{*}{$\begin{array}{l}\text { Благородство } \\
\text { пронсхождения }\end{array}$} & & Н3 корене кмагородна & $\begin{array}{l}\text { Кны стихиры на } \\
\text { «Господи воззвах», 1-я } \\
\text { стихира }\end{array}$ \\
\hline & & $\begin{array}{l}\text { ото князь рогскыX'b } \\
\text { полоцкня земия }\end{array}$ & Славник \\
\hline & & 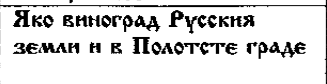 & $\begin{array}{l}\text { стихиры на «Господи } \\
\text { воззвах), Иғы стихиры, } \\
\text { глас тойже. } 2 \text {-я стихира }\end{array}$ \\
\hline \multirow[t]{4}{*}{ Чнстота } & & $\begin{array}{l}\text { YHCTOE CROE AERCTRO И } \\
\text { YECTHOE }\end{array}$ & $\begin{array}{l}\text { канон, после 3-й песни } \\
\text { Ин кондак, глас } 8\end{array}$ \\
\hline & & $\begin{array}{l}\text { YHCTPOTOHO TOCNOAEEH } \\
\text { YTOAHAA ECH }\end{array}$ & $\begin{array}{l}\text { после 6-й песни канона } \\
\text { Икос }\end{array}$ \\
\hline & & 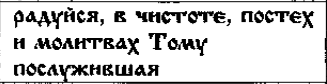 & $\begin{array}{l}\text { после 6-й песни канона } \\
\text { Икос }\end{array}$ \\
\hline & & naye orma yнстоты & $\begin{array}{l}\text { стихиры на «Господи } \\
\text { воззвах", стихнра 2-я }\end{array}$ \\
\hline Смирение & & 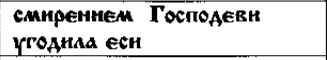 & $\begin{array}{l}\text { после 6-й песни канона } \\
\text { Икос }\end{array}$ \\
\hline Кротость & & 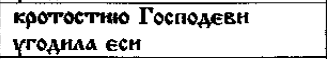 & $\begin{array}{l}\text { после 6-й песни канона } \\
\text { Икос }\end{array}$ \\
\hline Терпенне & & $\begin{array}{l}\text { YHCTOTOHO ГOCחOAEKH } \\
\text { YTOAHA ECИ }\end{array}$ & $\begin{array}{l}\text { после 6-й песни канона } \\
\text { Икос }\end{array}$ \\
\hline \multirow[t]{2}{*}{ Мнлосердне } & & $\begin{array}{l}\text { MHMOCEPAMEM ГOCTOAERH } \\
\text { YROAHAA ECH }\end{array}$ & $\begin{array}{l}\text { после 6-й песни канона } \\
\text { Икос }\end{array}$ \\
\hline & & 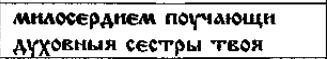 & Седален глас 8 \\
\hline \multirow[t]{2}{*}{ Воздержание } & \multirow{2}{*}{$\begin{array}{l}\text { «всех прсспевағощи } \\
\text { постом и молитвами } \\
\text { и бдения нощными» }\end{array}$} & 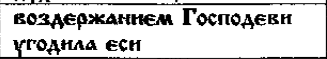 & $\begin{array}{l}\text { после 6-й песни канона } \\
\text { Икос }\end{array}$ \\
\hline & & $\begin{array}{l}\text { воздержанием поучаноци } \\
\text { АҮXонны сестры твоя }\end{array}$ & Седален глас 8 \\
\hline \multirow[t]{2}{*}{ Боголюбне } & $\begin{array}{l}\text { "ум ее еще больше } \\
\text { простирался к любви } \\
\text { Божией») }\end{array}$ & \multirow[t]{2}{*}{ 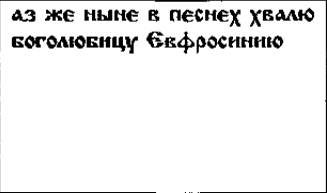 } & \multirow[t]{2}{*}{$\begin{array}{l}\text { утреня канон, после 3-й } \\
\text { песни, Ин икос }\end{array}$} \\
\hline & $\begin{array}{l}\text { «блаженная княгини, } \\
\text { удивившися разуму } \\
\text { отроковица и любви, } \\
\text { яже к Богу» }\end{array}$ & & \\
\hline \multirow[t]{2}{*}{ Мужество } & \multirow{2}{*}{$\begin{array}{l}\text { (прошла она с } \\
\text { мужскою твсрдостью } \\
\text { все города и } \\
\text { государства) }\end{array}$} & Aoycueto Moyłkeckoto & \multirow{2}{*}{$\begin{array}{l}\text { стихиры на «Господи } \\
\text { воззвах), стихира 1-я }\end{array}$} \\
\hline & & 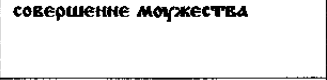 & \\
\hline \multirow[t]{3}{*}{ Христолюбие } & & 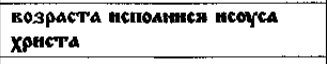 & $\begin{array}{l}\text { стихиры на «Господи } \\
\text { воззвах», стихира 1-я }\end{array}$ \\
\hline & & $\begin{array}{l}\text { вжелAвоши женнха } \\
\text { neтAbnнaro nсоүса }\end{array}$ & \multirow[t]{2}{*}{$\begin{array}{l}\text { стихиры на «Господи } \\
\text { воззвах», стихира } 3 \text {-я }\end{array}$} \\
\hline & & 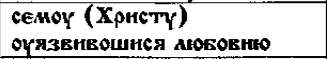 & \\
\hline \multirow[t]{2}{*}{ Духовность } & $\begin{array}{l}\text { «душа Святаго Духа } \\
\text { наполняшеся» }\end{array}$ & \multirow[t]{2}{*}{ 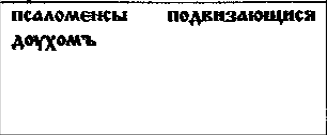 } & \multirow[t]{2}{*}{$\begin{array}{l}\text { стихиры на «Господи } \\
\text { воззвах», стихира 2-я }\end{array}$} \\
\hline & $\begin{array}{l}\text { «от Святаго Духа } \\
\text { наполняшеся мысли } \\
\text { ея») }\end{array}$ & & \\
\hline \multirow[t]{2}{*}{ Духовный свет } & & chathe вocnphimatom, & $\begin{array}{l}\text { стихиры на «Господн } \\
\text { воззвах», стихира } 2 \text {-я }\end{array}$ \\
\hline & & 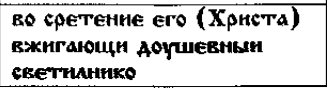 & $\begin{array}{l}\text { стихиры на «Господн } \\
\text { воззвах», стихира } 3-x\end{array}$ \\
\hline
\end{tabular}




\begin{tabular}{|c|c|c|}
\hline жаap & Drta & піғфр рукотиск \\
\hline \multirow[t]{8}{*}{ CMAEHHK 6-fo TMACA } & $\begin{array}{l}\uparrow \\
\text { sma xe ma }\end{array}$ & $\begin{array}{l}\text { РН6, К-Б. 586/843, } 1586 \text { т., } \\
\text { л. 572-572 06. }\end{array}$ \\
\hline & 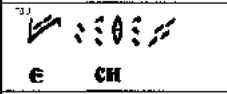 & \multirow[t]{4}{*}{$\begin{array}{l}\text { РНБ, Кап, О-472 (@-4), сер. } 17 \text { в } \\
\text { л. } 262 \text { 06.-263 }\end{array}$} \\
\hline & $\begin{array}{l}\text { Wo: } \\
\text { so } 10 \mathrm{sh}\end{array}$ & \\
\hline & 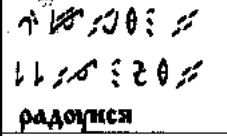 & \\
\hline & $\begin{array}{l}20 \\
\text { morockin }\end{array}$ & \\
\hline & 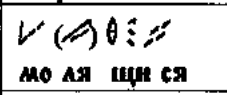 & \multirow[t]{3}{*}{$\begin{array}{l}\text { РГБ, Ф. } 379, \text { Nي } 65, \text { л. } 437-440 \\
\text { (БАН, Вят. 9, л. 493-494 об.) }\end{array}$} \\
\hline & 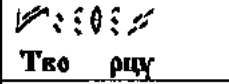 & \\
\hline & 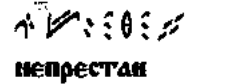 & \\
\hline \multirow[t]{2}{*}{ 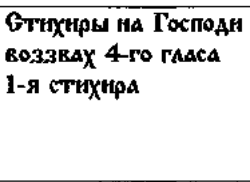 } & $\begin{array}{l}b \uparrow: \theta: 2 \\
\text { monpana ech }\end{array}$ & \multirow[t]{6}{*}{$\begin{array}{l}\text { РНБ, К.-Б. } 586 / 843,1586 \text { г., } \\
\text { л. } 572-57206 .\end{array}$} \\
\hline & $\begin{array}{l}\text { bo bot: } \\
\text { Mor we etra }\end{array}$ & \\
\hline \multirow[t]{2}{*}{ 2-я cTसX)1tpd } & 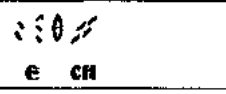 & \\
\hline & 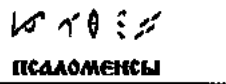 & \\
\hline \multirow[t]{2}{*}{ 3-я стехнира } & $\begin{array}{l}V \text { A } V^{\prime}: \theta z \\
\text { of Ao spe Hin } x\end{array}$ & \\
\hline & $\begin{array}{l}\text { Lotiti } \\
\text { e ch }\end{array}$ & \\
\hline
\end{tabular}

Второй глас воплощает смирение как путь к Богу и открывшейся Божественной Любви; суть гласа также включает сравнение и сопоставление переходных состояний от ветхого к новому, от естественного, непреображенного к святому. Это глас Предпразнеств, стихир Богородице, выражающих умиление, душевные тончайшие переживания, а также глас Божественной любви к людям, раскрытия тайны 
Неопалимой Купины. Он напоминает человеку о необходимости выхода из повседневности, греха, суеты, страстей.

Четвертый глас - это глас, призывающий к совершенству через Крестоношение и память о Животворящем Кресте Господнем; глас светлого торжества. Он наиболее употребим в Богослужении и большинство тропарей святителям и преподобным поются именно на этот глас; число 4, помимо указания на Животворящий Крест, указывает также на полноту земного мира и космоса (4 времени года, 4 стороны света, 4 стихии).

Шестой глас связан с покаянием и сокрушением о грехах; поскольку это один из самых глубоких гласов в передаче скорби и душевных переживаний, в нем часто можно услышать тему «смерти», «погребения», пребывания в глубокой ночи греха, несовершенства. Также глас воспевает аспект сошествия Спасителя в глубины ада, связует темы погребения и Воскресения. Кроме того, 6-й глас воплощает состояние духовного умиления, сосредоточенного самопознания, начала спасення, мягкости, простоты и душевности.

Итак, в результате проведенного сравнительного анализа систематизирован следующий список качеств-топосов, характеризующий духовный мир Евфросинии Полоцкой: душевная чистота, кротость, смирение, боголюбие и христолюбие, терпение, милосердие, мужество, духовность. На уровне вербально-певческой строки песнопений святой выявлены ключевые понятия духовно-религиозной жизни святой, маркированные особыми мелизматическими мелодическими оборотами - фитами: «блаженная», «Богови», «Творцу», «радуйся», «непрестанно», «молися», «мужества», «псаломенсы» (песнопения) и др. Таким образом, как житийные, так и певческие топосы службы древнерусской святой выявляют ключевые моменты ее духовного пути, связанные с молитвой и важнейшим рядом вышеуказанных христианских качеств.

«Створитеся, пшеница чиста, и смелитеся в жерновах смирением и молитвами и постом, да хлеб чист принесется на трапезу Христову», - говорит преподобная Евфросиния Полоцкая перед отъездом в Иерусалим братии и сестрам на прощание слова священномученика Игнатия Богоносца [8]. В этих словах сконцентрирован духовный комплекс свойств, необходимых на пути к Богу и освоенных самой святой - чистота, смирение, молитва и пост, отраженный в житийных и богослужебных текстах службы великой святой Древней Руси. 


\section{СПИСОК ЛИТЕРАТУРЫ}

1. Басова М. В. Евфросиния (Предслава) [Электронный ресурс] / М. В. Басова. - Режим доступа : http://www.pravenc.ru/text/187879.html

2. Воронова Е. М. Житие Евфросинии Полоцкой / Е. М. Воронова // Словарь книжников и книжности Древней Руси / отв. ред. Д. С. Лихачев. Л. : Наука, Ленингр. отд., 1987. - Вып. 1: XI - первая половина XIV в. C. $147-148$.

3. Всенощное бдение. Богослужебные песнопения Православной церкви / сост., ред., коммент. Дм. Болгарского. - К. : Издание Свято-Троицкого Ионинского монастыря, 2000.

4. Густова Л. А. Образ святой преподобной Евфросинии Полоцкой - просветительницы Белой Руси в гимнографии XII-XX столетий / Л. А. Густова // Древнерусское песнопение. Пути во времени: По материалам научной конференции «Бражниковские чтения-2004». - СПб. : Изд-во Политехн. ун-та, 2005. - Вып. 2. - С. 82-92.

5. Евфросиния [Электронный ресурс] // Православная энциклопедия. Режим доступа : http://www.pravenc.ru/text/187882.html

6. Житие преподобныя Евфросинии княжны Полотския (Из «Степенной книги» и «Сборника XVI в. Троицкой Лавры»). - Витебск : Издание Л. Сапунова, $1888 .-58 \mathrm{c}$.

7. Житие... преподобной Евфросинии, игумении Спаса-Вседержителя в граде Полоцке [Электронный ресурс] / подготовка текста и перевод Н. В. Понырко, комментарии В. К. Зиборова, А. В. Сиренова, Т. Г. Фруменковой. Режим доступа : http://lib.pushkinskijdom.ru/Default.aspx?tabid=10128

8. Карпов А. Ю. Евфросиния Полоцкая [Электронный ресурс]. - Режим доступа : http://www.portal-slovo.ru

9. Ключевский В. О. Древнерусские жития святых как исторический источник / В. О. Ключевский. - М. : Типография Грачева, 1871. - 480 с.

10. Кніга жыцій і хаджэнняў / уклад. Мельнікаў А. А. - Минск, 1994. C. $25-41$.

11. Малкова Н. А. Женский религиозно-нравственный идеал в культуре Древней Руси : дис. ... канд. культурологии : 24.00.01 - Теория и история культуры / Н. А. Малкова. - СПб., 2010. - 224 с.

12. Мельников А. А. Путь непечален: исторические свидетельства о святости Белой Руси / А. А. Мельников. - Минск : Бел. Экзархат, 1992. $243 \mathrm{c}$.

13. Мельнікаў А. А. Еўфрасіння Полацкая (Жыціе Еўфрасінні Полацкай з каментарыямі А. А. Мельнікава) / А. Мельнікаў // Мельнікаў А. А. 3 неапублікаванай спадчыны: Манаграфіi, артыкулы, вершы, матэрыялы навуковай канферэнцыі, успаміны сучаснікаў. - Минск : Чатыры чвэрці, 2005. - C. $14-315$.

14. Памятники старинной русской литературы / Изд. Г. КушелеваБезбородко. - СПб., 1862. - Т. 4. - С. 172-179. 
15. Почитание преподобной Евфросинии Полоцкой [Электронный ресурс]. - Режим доступа : http://spas-monastery.by/st_euphrosyne_of_polotsk/ worship.php?print $=\mathrm{Y}$

16. Преподобная Евфросиния, игумения Полоцкая. «Православное старообрядчество» [Электронный ресурс]. - Режим доступа : http://www. edinoslavie.ru/modules.php? name $=$ News\&file $=$ article $\&$ sid $=481$

17. Серегина Н. С. «Аз же ныне в пъснехъ хвалю...». К вопросу об авторе песнопений об Евфросинии Полоцкой и «Слова о полку Игореве»/ Н. С. Серегина // Музыкальная академия. - 2002. - № 1. - С. 95-100.

18. Серегина Н. С. Песнопения русским святым. По материалам рукописной певческой книги XI-XIX вв. «Стихирарь месячный» / Н. С. Серегина. - СПб., 1994. -469 с.

19. Симеон, священноинок. Канон преподобной Евфросинии Полоцкой. Предисловие [Электронный ресурс]. - Режим доступа: http://posad.1gb.ru/ default.aspx?ti $=1 \&$ hti $=36$

20. Степенная книга царского родословия // Полное собрание русских летописей. - СПб., 1908. - Т. 21, ч. 1. - С. 206-220.

Каплун Т. Преподобна Свфросинія Полоцька у давньоруській співацькій та житійній традиціi. У статті розглянуті духовні і співацькі аспекти втілення образу святої Євфросинії Полоцької у давньоруській житійній та богослужбовій традиції.

Ключові слова: святість, житіє святих, давньоруська співацька традиція, православне богослужіння, Свфросинія Полоцька, поетика образу.

Kaplun T. Euphrosyne of Polotsk in Old Russianchurch chant and hagiographic tradition. In the article the spiritual and church singing aspects of embodiment of appearance are considered saint of Euphrosyne of Polotsk in Old Russian hagiographicand church chanttradition.

Key words: holiness, life of saints, Old Russian church singing, orthodox divine service, Euphrosyne of Polotsk, poetics of appearance.

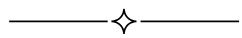

